\title{
20: 61337721-61342299
}

National Cancer Institute

\section{Source}

National Cancer Institute. 20:61337721-61342299. NCI Thesaurus. Code C41782.

Physical location of BIRC7_Gene 